\title{
FAKTOR FAKTOR PEMILIHAN METODE KONTRASEPSI SUNTIK PROGESTIN PADA WANITA USIA SUBUR DI BPS NY.S
}

\author{
Evi Zulfiana ${ }^{1}$ \\ Email : Evi.Zulfiana33Yahoo.com \\ ${ }^{1}$ DIII Kebidanan Politeknik Harapan Bersama \\ Jalan Mataram N0 9 Kota Tegal 52142 \\ Tlpn (0283) 352000
}

\begin{abstract}
Abstrak
Penggunaan kontrasepsi suntik selalu menempati urutan pertama dari tingkat Nasional, Provinsi, Kota / Kabupaten. Penelitian ini bertujuan untuk mengetahui gambaran faktor - faktor pemilihan metode kontrasepsi suntik progestin di BPS Ny S. metode penelitian ini adalah deskriptif, populasi dari penelitian ini adalah ibu pengguna kontrasepsi suntik di BPS Ny S, tehnik penggunaan pengambilan sampel pada penelitian ini adalah accidental sampling. Data dikumpulkan dengan menggunakan kuesioner 50 responden. Hasil penelitian ini menunjukan bahwa sebagian besar umur responden yang menggunakan kontrasepsi suntik berumur 20 - 30 tahun yaitu mencapai $70 \%$ yang menginginkan anak 2 saja mencapai $50 \%$ yang tidak pernah pernah mengikuti sebelumnya mencapai $68 \%$ yang mengalami siklus haid teratur $96 \%$.
\end{abstract}

Kata Kunci : Faktor-factor Pemilihan, WUS, Kontrasepsi Progestin

\section{Pendahuluan}

Pelayanan Keluarga Berencana berkualitas merupakan kewajiban pemerintah dan pemberi layanan untuk menyediakannya. Tuntutan pelayanan ini dipengaruhi dengan semakin meningkatnya pengetahuan masyarakat terhadap kesehatan termasuk.

Menurut WHO Keluarga Berencana adalah tindakan yang membantu individu atau pasangan suami istri untuk mendapat objektif - objektif tertentu, menghindari kehamilan yang tidak diinginkan, mengatur interval antara kehamilan. Data peserta kontrasepsi di BPS Ny S terbanyak adalah kontrasepsi suntik, suntik selalu yang terbanyak dibadingkan kontrasepsi yang lain, untuk itu penulis ingin mengetahui Faktor-faktor akseptor memilih alat kontrasepsi suntik di BPS Ny S.

\section{Metode Penelitian}

Jenis penelitian yang digunakan menggunakan penelitian deskriptif untuk membuat gambaran tentang suatu keadaan secara objektif dengan melihat faktor faktor pemilihan kontrasepsi progestin. kriteria pada penelitian ini adalah criteria eksklusi seperti ibu yang memenuhi criteria inklusi namun tidak mau menjadi responden karena sebab tertentu. Dan di dapatkan sampel 50 responden.

Penelitian dilakukan dengan membagi kuesioner dan wawancara mendalam yang kemudian data dilakukan analisis univariat yaitu analisis yang dilakukan pada tiap variable yang menghasilkan distribusi dan presentase dari tiap variable.

\section{Hasil dan Pembahasan}

Hasil penelitian ini dilakukan dalam satu tingkatan analisis yaitu analisis univariat yang menggambarkan distribusi frekuensi dari setiap variable penelitian yang meliputi : umur ibu,jumlah anak yang diinginkan, pengalaman kontrasepsi yang lalu, siklus haid, efek samping. Adapun distribusi frekuensi tersebut antara lain :

Tabel 1. Distribusi Frekuensi Responden berdasarkan umur

\begin{tabular}{lcc}
\hline $\begin{array}{l}\text { Distribusi } \\
\text { Responden }\end{array}$ & Frekuensi & $\%$ \\
\hline Umur & & \\
$<20$ tahun & 35 & 0 \\
20-30 tahun & 15 & 70 \\
$>30$ tahun & & 30 \\
& & \\
Berdasarkan & penelitian & menunjukan \\
bahwa sebagian besar responden berumur \\
20 -30 tahun sebanyak $35(70 \%)$. Pada usia
\end{tabular}


ini wanita tidak hanya produktif dalam reproduksi tapi juga wanita wanita produktif dalam hal ekonomi sehingga banyak yang mengikuti kontrasepsi suntik karena kontrasepsi suntik sangat praktis dan efisien. Menurut hartanto (2004) periode umur 20 30 tahun merupakan fase untuk menjarangkan kehamilan.

Tabel 2. Distribusi Frekuensi Responden berdasarkan anak yang diinginkan

\begin{tabular}{|c|c|c|}
\hline $\begin{array}{l}\text { Distribusi } \\
\text { Responden }\end{array}$ & Frekuensi & $\%$ \\
\hline Anak yg diinginkan & & \\
\hline$<2$ & 8 & 16 \\
\hline 2 & 25 & 50 \\
\hline$>2$ & 17 & 34 \\
\hline
\end{tabular}

Sebagian responden menginginkan anak 2 saja yaitu mencapai $25(50 \%)$, hal ini sesuai dengan program pemerintah dengan memiliki 2 anak lebih baik. Menurut hartanto pelayanan kontrasepsi bertujuan dalam pemberian dukungan dan pemantapan penerimaaan gagasan KB yaitu dihayatinya norma keluarga kecil bahagia dan sejahtera (NKKBS).

Tabel 3. Distribusi Frekuensi Responden berdasarkan pengalaman

\begin{tabular}{lcc}
\hline $\begin{array}{l}\text { Distribusi } \\
\text { Responden }\end{array}$ & Frekuensi & $\%$ \\
Pengalaman & & \\
Pernah & 16 & 32 \\
Tidak pernah & 34 & 68
\end{tabular}

Dari hasil penelitian sebagian besar responden ak pernah menggunakan kontrasepsi 34 (68\%), dan ini merupakan hal yang baru dalam menggunakan kontrasepsi, responden mendengar pengalaman orang lain sehingga tertarik untuk memilih kontrasepsi suntik, dari pengalaman responden yang pernah menggunakan alat kontrasepsi suntik dirasakan tidak ada keluhan yang dirasakan. Menurut hanafi kontrasepsi suntik progestin memiliki efektifitas yang tinggi dengan 0,3 kehamilan per 100 perempuan asal penyuntikannya dilakukan teratur sesuai dengan jadwal yang telah ditentukan.
Tabel 4. Distribusi Frekuensi Responden berdasarkan siklus haid

\begin{tabular}{lll}
\hline $\begin{array}{l}\text { Distribusi } \\
\text { Responden }\end{array}$ & Frekuensi & $\%$ \\
\hline Siklus haid & & \\
Teratur & 48 & 96 \\
Tidak teratur & 2 & 4
\end{tabular}

Dari hasil penelitian sebagian besar responden menggunakan kontrasepsi suntik mengalami siklus haid yang teratur yaitu 48 (96\%). Menurut hartanto bahwa siklus haid merupakan salah satu factor dalam memilih kontrasepsi.

Tabel 5. Distribusi Frekuensi Responden berdasarkan Efeksamping

\begin{tabular}{lll}
\hline Distribusi & Frekuensi & $\%$ \\
Responden & & \\
\hline Efek Samping & & \\
Ada & 3 & 6 \\
Tidak ada & 47 & 94
\end{tabular}

Sebagian besar responden tidak ada efeksamping 47 (94\%) dan yang mengalami efeksamping 3 (6\%) diantaranya peningkatan berat badan akan tetapi hal ini tidak berbahaya, namun perlu mendapat perhatian bagi petugas yang memberikan pelayanan untuk dapat menjelaskan tentang kemungkinan terjadinya efek samping, seperti yang disampaikan saifudin (2003) bahwa efek samping dari kontrasepsi progestin adalah kenaikan berat badan 1-5 $\mathrm{kg}$.

\section{Kesimpulan}

Hasil penelitian menunjukan bahwa akseptor yang memilih kontrasepsi progestin rata - rata berumur 20-30 tahun70 $\%$, yang menginginkan anak $250 \%$, Responden yang tidak pernah menggunakan kontrasepsi suntik progestin sebelumnya $68 \%$, siklus haid teratur $96 \%$ dan yang tidak pernah mengalami efek samping 94\%, sebagian kecil ada yang mengalami efeksamping akan tetapi tidak berbahaya, untuk itu Bidan memiliki peran penting untuk menjelaskan tentang kontrasepsi progestin secara jelas sehingga akseptor mengetahui bahwa setiap kontrasepsi tidak $100 \%$ tingkat keberhasilannya tapi ada tingkat kegagalannya serta efeksamping. 


\section{Daftar Pustaka}

[1] Departemen Kesehatan RI. 2002. Buku Pedoman Petugas Fasilitas Pelayanan Keluarga Berencana. Jakarta: Pusat Pendidikan Tenaga Kesehatan.

[2] Dinas Kesehatan. 2006. Profil Kesehatan Provinsi Jawa Tengah. Semarang : Dinas Kesehatan Provinsi Jawa Tengah

[3] Hanafi. 2003. Keluarga Berencana. Jakarta : Nuha Medika.

[4] Hartanto. 2004. Keluarga Berencana dan Kontrasepsi. Jakarta: Pustaka Sinar Harapan.

[5] Manuaba.I.B.G. 2002. Reproduksi Kontrasepsi dan Keluarga Berencana. Jakarta: Kanisius.

[6] Prawirohardjo.2008. Ilmu Kandungan. Jakarta: Yayasan Bina Pustaka Sarwono Prawirohardjo.

[7] Saifudin. 2004. Buku Panduan Praktis Pelayanan Kontrasepsi. Jakarta : Yayasan Bina Pustaka Sarwono Prawirohardjo.

[8] Wiknjosastro. 2006. Ilmu Kebidanan. Bina Pustaka SarwonoPrawirohardjo 